\title{
FOLFIRI plus panitumumab in the treatment of wild-type KRAS and wild-type NRAS metastatic colorectal cancer
}

\author{
Caglayan Geredeli* and Nurgul Yasar
}

\begin{abstract}
Background: The aim of this study was to investigate the efficacy and safety of first-line panitumumab plus folinic acid, 5-fluorouracil and irinotecan (FOLFIRI) in patients with wild-type KRAS and wild-type NRAS metastatic colorectal cancer (mCRC).

Methods: Patients with wild-type KRAS and wild-type NRAS mCRC presenting to the medical oncology department of the Okmeydani Training and Research Hospital in Istanbul, Turkey, between April 2014 and January 2018 were enrolled in this study.

Results: A total of 64 patients ( 35 males and 29 females) with a median age of 59 (35-81) years old were enrolled. The median follow-up was 18.9 months, and the median progression-free survival was 13 months. The median overall survival (OS) was 26 months in the patients with wild-type KRAS and wild-type NRAS mCRC. It was 90. $4 \%$ for the 6-month OS, $79.5 \%$ for the 1-year OS, 53.7\% for the 2-year OS and 31.1\% for the 3-year OS. The median OS of the patients who underwent metastasectomies was 40 [95\% confidence interval $(\mathrm{Cl})=19.9-60.1]$ months, and the median OS of the patients without metastasectomies was 22 (95\% Cl=17.7-26.4) months. There was a statistically significant difference between these $(P=0.007)$.

Conclusion: The first-line FOLFIRI plus panitumumab was associated with favourable efficacy in the patients with wild-type KRAS and wild-type NRAS MCRC, and it was well tolerated. The removal of the metastases that became resectable after chemotherapy further prolonged the patients' survival.
\end{abstract}

Trial registration: Retrospectively registered: 33886

Keywords: FOLFIRI, Panitumumab, Colorectal cancer

\section{Background}

Folinic acid, infusional 5-fluorouracil and irinotecan (FOLFIRI) is a regimen recommended for use as both a first-line and second-line treatment for metastatic colorectal cancer (mCRC) [1]. Epidermal growth factor receptor (EGFR) inhibitors (panitumumab and cetuximab) can be used in combination with folinic acid, infusional 5-fluorouracil and oxaliplatin (FOLFOX) and FOLFIRI regimens in the treatment of wild-type KRAS (Kirsten rat sarcoma viral oncogene homologue) and wild-type

* Correspondence: caglayange@hotmail.com

Department of Medical Oncology, Okmeydani Training and Research Hospital, Sisli, Istanbul, Turkey
NRAS mCRC patients [2]. The combination of an EGFR inhibitor plus the FOLFOX or FOLFIRI regimen has improved survival in first- and second-line treatments [2-7]. Initially, the combination of panitumumab plus FOLFOX was used in the treatment of mCRC patients, and it was found to be effective without impairing the quality of life $[8,9]$. For the second-line treatment of wild-type RAS (both wild-type KRAS and wild-type NRAS) mCRC patients, the panitumumab plus FOLFIRI regimen was found to be superior to the FOLFIRI regimen alone with regard to the disease-free survival [10]. In a few studies, the FOLFIRI plus panitumumab regimen was found to be effective and safe for the first-line treatment of wild-type 
KRAS mCRC patients [11-14]. Here, we would like to present our single-centre experience regarding the efficacy and safety of the FOLFIRI plus panitumumab regimen as the first-line treatment in wild-type KRAS and wild-type NRAS mCRC patients.

\section{Methods}

Wild-type KRAS and wild-type NRAS mCRC patients followed up at the medical oncology department of the Okmeydani Training and Research Hospital in Istanbul, Turkey, between April 2014 and January 2018 were enrolled in this retrospective study. After examining their files, those patients with histologically confirmed colon cancer diagnoses, radiologically confirmed metastases, genetically established KRAS and NRAS statuses and performance statuses of $0-2$ on the Eastern Cooperative Oncology Group (ECOG) scale were included in this study. The KRAS and NRAS analyses were conducted using a real-time polymerase chain reaction (PCR) on the DNA extracted from fixed tumour sections. We performed a two-round nested PCR for the amplification of exons 1,2 and 3 of the KRAS and NRAS genes harbouring codons 12, 13, 59, 61, 117 and 146. This was followed by a multiplex mini-sequencing reaction for the detection of potential mutations.

As a first-line treatment, panitumumab $(6 \mathrm{mg} / \mathrm{kg})$, FOLFIRI (irinotecan $\left(180 \mathrm{mg} / \mathrm{m}^{2}\right)$ and leucovorin $\left(400 \mathrm{mg} / \mathrm{m}^{2}\right)$, followed by a $400 \mathrm{mg} / \mathrm{m}^{2}$ bolus of 5 fluorouracil and a $2400-3000 \mathrm{mg} / \mathrm{m}^{2}$ continuous infusion regimen, was administered every 14 days for 6 cycles. In addition, $100 \mathrm{mg}$ of doxycycline (twice daily) and corticosteroid creams were used during the chemotherapy to reduce the dermatological side effects of the panitumumab. This was a prophylactic treatment started after the chemotherapy treatment actually caused skin toxicity.

The patients were evaluated using radiological imaging methods [computed tomography (CT)] every 8 weeks according to the Response Evaluation Criteria in Solid Tumours (RECIST1.1) criteria. The objective response rate (ORR), progression-free survival (PFS) and overall survival (OS) durations were calculated. The safety was evaluated in terms of the incidence and severity of adverse events (AEs), using the National Cancer Institute common toxicity criteria version 3.0.

The Statistical Package for the Social Sciences (SPSS) version 15.0 for Windows was used for the statistical analysis. The descriptive statistics were expressed as the mean, standard deviation, minimum, maximum and median for the numerical variables, and they were expressed as numbers and percentages for the categorical variables. If the numerical variables of two independent groups were not normally distributed, they were analysed using a Mann-Whitney $U$ test. A chi- squared test was used for the comparisons of the ratios in the groups, and a Monte Carlo simulation was applied when the conditions were not met. The survival analyses were conducted with a Kaplan-Meier analysis, and the statistical significance level of alpha was accepted as $p<0.05$.

\section{Results}

A total of 64 patients were enrolled in this study. The median age was 59 years old (range $=35-81$ years): 35 patients were males and 29 were females. From a localization point of view, 56 patients had left colon tumours $(87.5 \%)$, and 8 patients had right colon tumours (12.5\%). While $45(70.3 \%)$ patients were diagnosed with synchronous metastases, and $19(29.7 \%)$ patients had metachronous metastases. During the follow-up period, 46 (71.9\%) had liver metastases, 7 (10.9\%) had lung metastases, 4 (6.3\%) had bone metastases, 4 (6.3\%) had peritoneal metastases and $3(4.7 \%)$ had remote lymph node metastases (Table 1). The median follow-up duration was 18.9 months. Progression was seen in 50 (78.1\%) patients, while 14 (21.9\%) showed no progression. Thirty-three (51.6\%) patients died during the follow-up (Table 1).

After 8 weeks of therapy, the evaluation of the response rates indicated that a complete response (CR) was achieved in 3 patients (4.7\%), 50 (78.1\%) showed a partial response (PR), 5 had stable disease (SD) (7.8\%) and $6(9.4 \%)$ had progressive disease (PD) (Table 2). The median PFS of the wild-type KRAS and wild-type NRAS $\mathrm{mCRC}$ patients was 13 [95\% confidence interval $(\mathrm{CI})=$ 9.6-16.4] months (Fig. 1), with 77.3\% 6-month, 50.1\% 1year, 16.9\% 2-year and 3.4\% 3-year survivals (Table 2). FOLFOX-bevacizumab was administered as second-line chemotherapy in $40(62.5 \%)$ of the $50(78.1 \%)$ patients with disease progression during the follow-up period of 18.9 months (Table 1). The median OS was 26 (95\% CI = 23-29) months (Fig. 2), with 90.4\% 6-month, 79.5\% 1year, 53.7\% 2-year and 31.1\% 3-year survivals (Table 2). The median PFS was 4. (95\% CI $=1.5-6.5)$ months for the patients with right colon tumours. In contrast, it was 14 (95\% CI $=10.8-17.2)$ months for the patients with left colon tumours, and the difference was statistically significant $(P=0.02)$. The median OS was $18(95 \% \mathrm{CI}=$ 5.3-30.7) months in the patients with right colon tumours and $26(95 \% \mathrm{CI}=23.1-28.9)$ months in the patients with left colon tumours (Table 2) (Fig. 3). This difference was also statistically significant $(P=0.02)$.

Of the patients, $17(26.6 \%)$ underwent metastasectomies, and of these, 15 (13.4\%) underwent metastasectomies for liver metastases and 2 (3.1\%) underwent metastasectomies for lung metastases. The median PFS of the patients who underwent metastasectomies was 17 (95\% CI $=14.3-19.7)$ months, and the median PFS of the 
Table 1 Patient characteristics

\begin{tabular}{|c|c|c|c|}
\hline \multicolumn{2}{|l|}{ Characteristics } & \multirow{2}{*}{$\frac{n}{29}$} & \multirow{2}{*}{$\begin{array}{l}\text { Percentile (\%) } \\
45.3\end{array}$} \\
\hline Sex & Female & & \\
\hline & Male & 35 & 54.7 \\
\hline \multirow[t]{2}{*}{ Pathology } & Adenocarcinoma & 61 & 95.3 \\
\hline & Mucinous & 3 & 4.7 \\
\hline \multirow[t]{3}{*}{ Grade } & । & 4 & 6.3 \\
\hline & $\|$ & 57 & 89.1 \\
\hline & III & 3 & 4.7 \\
\hline KRAS & Wild & 64 & 100 \\
\hline NRAS & Wild & 64 & 100 \\
\hline \multirow[t]{2}{*}{ Biopsy location } & Primary tumour & 61 & 95.3 \\
\hline & Metastasis & 3 & 4.7 \\
\hline \multirow[t]{2}{*}{ Metastasis diagnosed } & Synchronous & 45 & 70.3 \\
\hline & Metachronous & 19 & 29.7 \\
\hline \multirow[t]{3}{*}{ Right colon } & Total & 8 & 12.5 \\
\hline & Ascending colon & 5 & 7.8 \\
\hline & Transverse colon & 3 & 4.7 \\
\hline \multirow[t]{4}{*}{ Left colon } & Total & 56 & 87.5 \\
\hline & Rectum & 21 & 32.8 \\
\hline & Sigmoid colon & 33 & 51.6 \\
\hline & Descending colon & 2 & 3.1 \\
\hline \multirow[t]{5}{*}{ Metastasis location } & Liver & 46 & 71.9 \\
\hline & Lung & 7 & 10.9 \\
\hline & Peritoneum & 4 & 6.3 \\
\hline & Bone & 4 & 6.3 \\
\hline & Remote lymph node & 3 & 4.7 \\
\hline \multirow[t]{2}{*}{ Metastasectomy } & Yes & 17 & 26.5 \\
\hline & No & 47 & 73.5 \\
\hline \multirow[t]{2}{*}{ Second treatment } & Yes & 40 & 62.5 \\
\hline & No & 24 & 37.5 \\
\hline \multirow[t]{2}{*}{ Progression } & Yes & 50 & 78.1 \\
\hline & No & 14 & 21.9 \\
\hline \multirow[t]{2}{*}{ Death } & Yes & 33 & 51.5 \\
\hline & No & 31 & 48.5 \\
\hline
\end{tabular}

patients without metastasectomies was $8(95 \% \mathrm{CI}=5.6-$ 10.4) months. The median PFS of the metastasectomy patients was statistically significantly longer $(P=0.02)$. The median OS of the patients who underwent metastasectomies was 40 (95\% CI=19.9-60.1) months, and the median OS of the patients without metastasectomies was $22(95 \% \mathrm{CI}=17.7-26.4)$ months. There was a statistically significant difference between these values $(P=0.007)$ (Table 2) (Fig. 4).

The PFS was $12(95 \% \mathrm{CI}=7-17)$ months in the patients with synchronous metastases, and the PFS was $17(95 \% \mathrm{CI}=3.6-30.4)$ months in those with metachronous metastases. However, no statistical difference was found $(P=0.28)$. The OS was 26 (95\% CI $=21.7-30.3)$ months in those with metachronous metastasis, and it was $23(95 \% \mathrm{CI}=16.9-29.1)$ months in those with synchronous metastases. No statistical difference was found between them $(P=0.21)$ (Table 2).

The assessment of toxicity showed that the most frequently occurring symptoms of grade $1 / 2$ toxicities were an acne-like rash (60.9\%), diarrhoea (36.2\%) and neutropenia $(34.7 \%)$. Similarly, the most frequently occurring symptoms of grade $3 / 4$ toxicities were diarrhoea $(4.7 \%)$, an acne-like rash (6.3\%) and neutropenia (9.2\%) (Table 2).

\section{Discussion}

In our study, we evaluated the effects of the combination of panitumumab, an anti-EGFR drug, and FOLFIRI chemotherapy on the patients' survival. In the PRIME trial, after using panitumumab plus FOLFOX as the first-line treatment, the PFS was 10.1 months and the OS was 26 months in the wild-type RAS patients [15]. The 26-month OS outcomes of both the wild-type RAS mCRC patients in our study were found to be identical to those of the 26-month OS in the PRIME trial.

In the PEAK trial, after using the panitumumab plus FOLFOX as the first-line treatment in $\mathrm{mCRC}$ patients in that trial, the PFS was 13.0 months and the OS was 41.3 months in the wild-type RAS patients [8]. The 13month PFS outcomes of wild-type RAS mCRC patients in our study were found to be identical to those of the 13-month PFS in the PEAK study. The 26-month OS outcomes of wild-type RAS mCRC patients in our study were found to be lower than those of the 41.3-month OS in the PEAK study.

In the CRYSTAL study that was conducted with cetuximab (another anti-EFGR drug), the PFS was 11.4 months and the OS was 28.4 months in the wild-type RAS patients who received FOLFIRI plus cetuximab [15]. Our findings of 13 months for the PFS and 26 months for the OS were similar to those of the 11.4-month PFS and 28.4-month OS in the CRYSTAL study results. Moreover, in the FIRE-3 trial, the PFS in the wild-type RAS mCRC patients was 10.4 months and the OS was 33.1 months [16]. Our 13-month PFS result was longer than the 10.4-month PFS result from the FIRE-3 trial, but the 26-month OS result was shorter than that of the 33.1-month OS from that trial. Finally, the CAPRI-GOIM trial used FOLFIRI plus cetuximab, and the median PFS was 11.1 months in the wild-type RAS mCRC patients [17].

In the first prospective phase 2 trial using a FOLFIRI plus panitumumab combination in wild-type KRAS 
Table 2 Response, PFS, OS and toxicity rate

\begin{tabular}{|c|c|c|c|}
\hline Response to treatment & $n$ & $\%$ & $p$ \\
\hline Complete response & 3 & 4.7 & \\
\hline Partial response & 50 & 78.1 & \\
\hline Stable disease & 5 & 7.8 & \\
\hline Progressive disease & 6 & 9.4 & \\
\hline $\begin{array}{l}\text { Wild-type KRAS and } \\
\text { NRAS PFS }\end{array}$ & Months or $\%$ & \%95 Cl (min-max) & \\
\hline Median follow-up & 18.9 & $2.0-51.0$ & \\
\hline Median PFS & 13 & $9.6-16.4$ & \\
\hline 6-months PFS & 77.3 & & \\
\hline 1-year PFS & 50.1 & & \\
\hline 2-year PFS & 16.9 & & \\
\hline 3-year PFS & 3.4 & & \\
\hline \multicolumn{4}{|l|}{$\begin{array}{l}\text { Wild-type KRAS and } \\
\text { NRAS OS }\end{array}$} \\
\hline Median OS & 26 & $23.1-29.2$ & \\
\hline 6-months OS & 90.4 & & \\
\hline 1-year OS & 79.5 & & \\
\hline 2-year OS & 53.7 & & \\
\hline 3-year OS & 31.1 & & \\
\hline \multicolumn{4}{|l|}{ Tumour location } \\
\hline Right colon PFS & 4 & $1.5-6.5$ & 0.02 \\
\hline Left colon PFS & 14 & $10.8-17.2$ & \\
\hline Right colon OS & 18 & $5.3-30.7$ & 0.02 \\
\hline Left colon OS & 26 & $23.1-28.9$ & \\
\hline \multicolumn{4}{|l|}{ Metastasectomy } \\
\hline Yes PFS & 17 & $14.3-19.7$ & 0.02 \\
\hline No PFS & 8 & $5.6-10.4$ & \\
\hline Yes OS & 40 & $19.9-60.1$ & 0.007 \\
\hline No OS & 22 & $17.7-26.4$ & \\
\hline \multicolumn{4}{|l|}{ Metastases diagnosed } \\
\hline Synchronous PFS & 12 & $7.0-17.0$ & 0.28 \\
\hline Metachronous PFS & 17 & $3.6-30.4$ & \\
\hline Synchronous OS & 23 & $16.9-29.1$ & 0.21 \\
\hline Metachronous OS & 26 & $21.7-30.3$ & \\
\hline Toxicity & Grade (all) & Grade (1-2) & Grade (3-4) \\
\hline Acne-like rash & $\% 60.9$ & $\% 54.6$ & $\% 6.3$ \\
\hline Diarrhoea & $\% 36.2$ & $\% 31.5$ & $\% 4.7$ \\
\hline Neutropenia & \%34.7 & $\% 25.5$ & $\% 9.2$ \\
\hline
\end{tabular}

PFS progression-free survival, OS overall survival

patients, the time to progression (TTP) was reported as 11.2 months by Köhne et al. [10]. In a study by Karthaus et al., the PFS was 11.2 months in the wild-type KRAS patients [18]. The PFS was 13 months for the wild-type RAS patients in our study, showing that our results were better than those of Karthaus and Köhne et al.
In this study, even though our patient number was low, we also analysed the tumour localization rates, which have recently become a highly discussed topic. In the retrospective analyses indicating the tumour localization [19, 20], the PFS was 7.5-8.7 months (7.5-7.6-8.1-8.7) in the right colon patients and 10.7-14.6 months (10.7-11.1-12-14.6) in the left colon patients for those using the FOLFIRI plus cetuximab and FOLFOX plus panitumumab regimens in the PRIME study, FIRE-3 study, CRYSTAL study and PEAK study. Furthermore, in the PRIME study, PEAK study, FIRE 3 study and CRYSTAL study, the OS was 11.1-18.5 months (11.1-17.5-18.3-18.5) in the right colon patients and 28.7-43.4 months (28.7$30.3-38.3-43.4)$ in the left colon patients $(21)[19,20]$. Out of the 64 patients in our study, only 8 had right colon tumours. The PFS was 4 months in the patients with right colon tumours and 14 months in those with left colon tumours. We found that OS was 18 months in the patients with right colon tumours and 26 months in those with left colon tumours. There was a statistically significant difference regarding the tumour localization $(p=0.02)$.

Although the patient groups and chemotherapy regimens differed, many studies have shown that patients with $\mathrm{mCRC}$ with limited metastases undergoing only liver metastasectomies may exhibit prolonged survival if the metastases become resectable after chemotherapy [21-29]. In the subgroup analyses of the Köhne et al. and CRYSTAL studies, in the wild-type RAS patients with liver-limited disease being treated with FOLFIRI plus cetuximab, the PFS was 14 months and the OS was 29.8 months [26]. In our study, the PFS was 17 months and the OS was 40 months in the patients who had liver metastases resected after FOLFIRI plus panitumumab chemotherapy. The removal of metastases that become resectable after chemotherapy can further prolong the patient's survival.

In our retrospective study, the diarrhoea rate was $36.2 \%$ and that of an acne-like rash was $60.9 \%$ in all the grades. In the study by Köhne et al., the rate of diarrhoea was $23 \%$ and that of dermatological toxicity was $29 \%$ [11]. Although our rates seemed to be higher than the rates in Köhne et al.'s study, other studies have reported higher diarrhoea and dermatological toxicity rates [30]. In the PEAK study, serious AEs were observed in $7 \%$ of the wild-type KRAS mCRC patients using FOLFOX plus panitumumab [8]. In our study, $4.7 \%$ diarrhoea and $6.3 \%$ acne-like rash rates occurred as grade $3 / 4$ toxicity symptoms. Our rates of serious AEs were found to be very similar to the results of the PEAK study. In our study, we observed that the diarrhoea and skin toxicity, which are the most common side effects of the FOLFIRI plus panitumumab regimen, could be easily managed with 


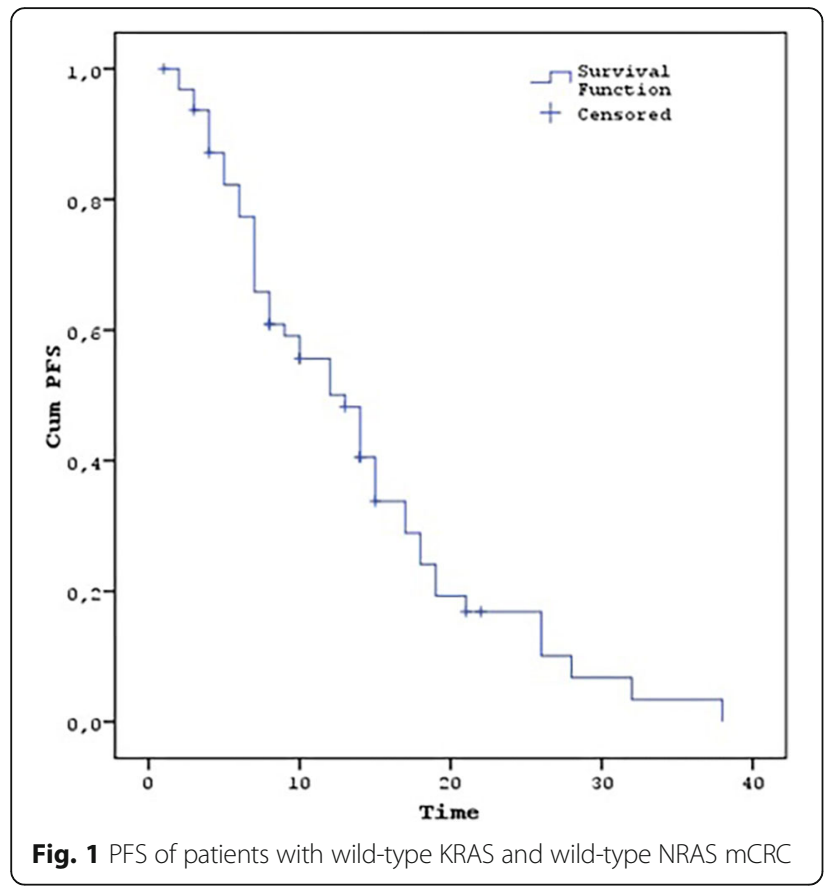

prophylactic precautions (100 mg of doxycycline twice per day, as well as antibiotic and corticosteroid creams) used after the chemotherapy-induced skin toxicity develops.

\section{Conclusions}

The results of this study showed that a first-line panitumumab plus FOLFIRI treatment was associated with favourable efficacy in patients with wild-type RAS

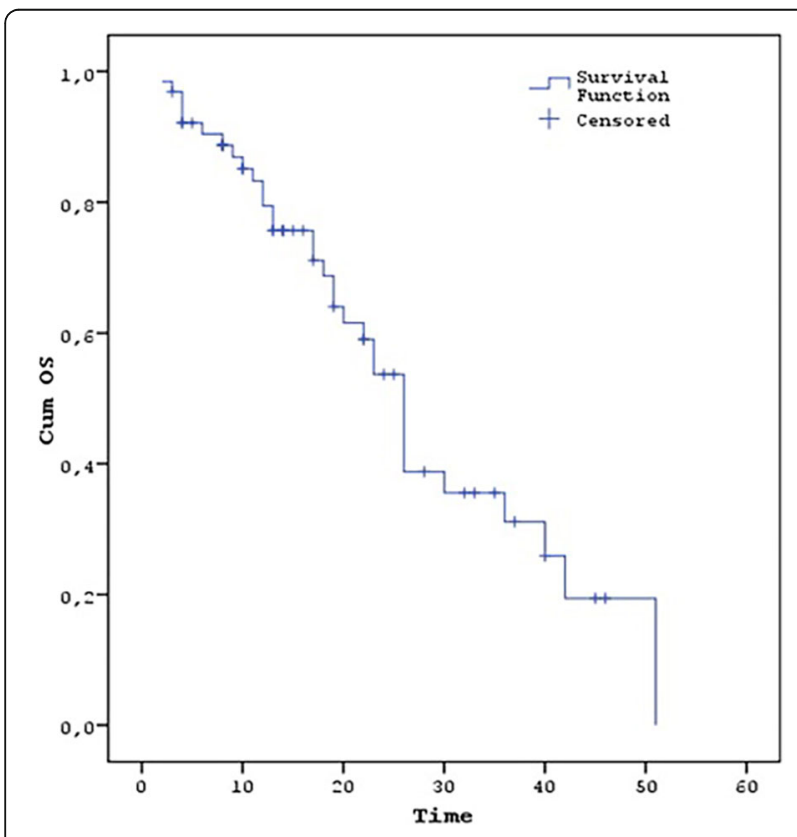

Fig. 2 OS of patients with wild-type KRAS and wild-type NRAS mCRC

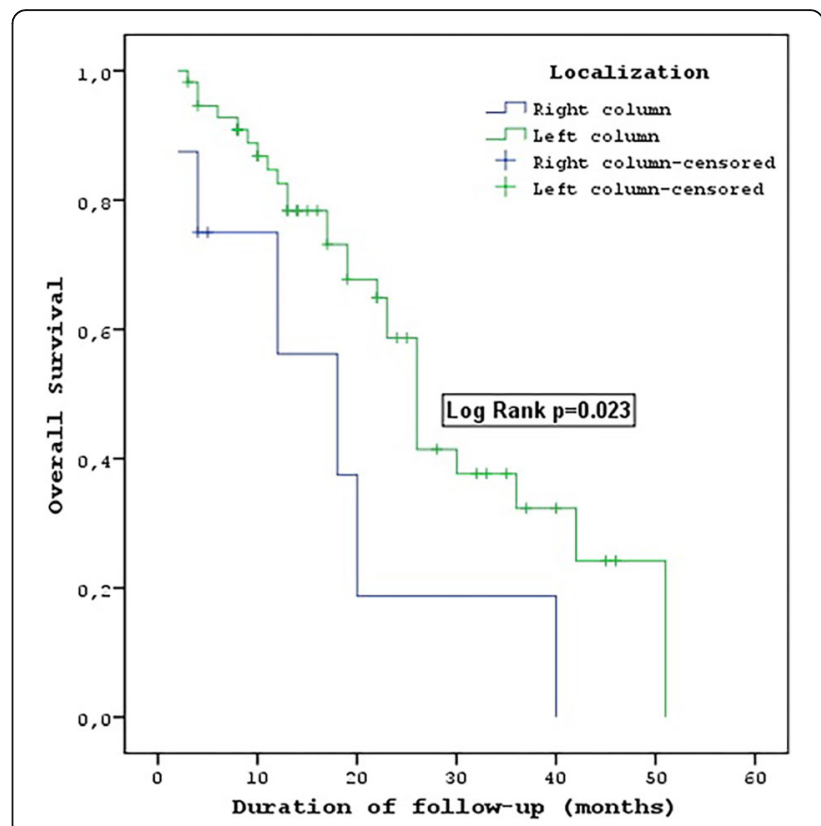

Fig. 3 OS tumour location patients with wild-type KRAS and wild-type NRAS MCRC

mCRC, and it was well tolerated. FOLFIRI plus panitumumab is much more effective in left colon tumours but is largely ineffective in right colon tumours. The removal of metastases that become resectable after chemotherapy can further prolong the patient's survival.

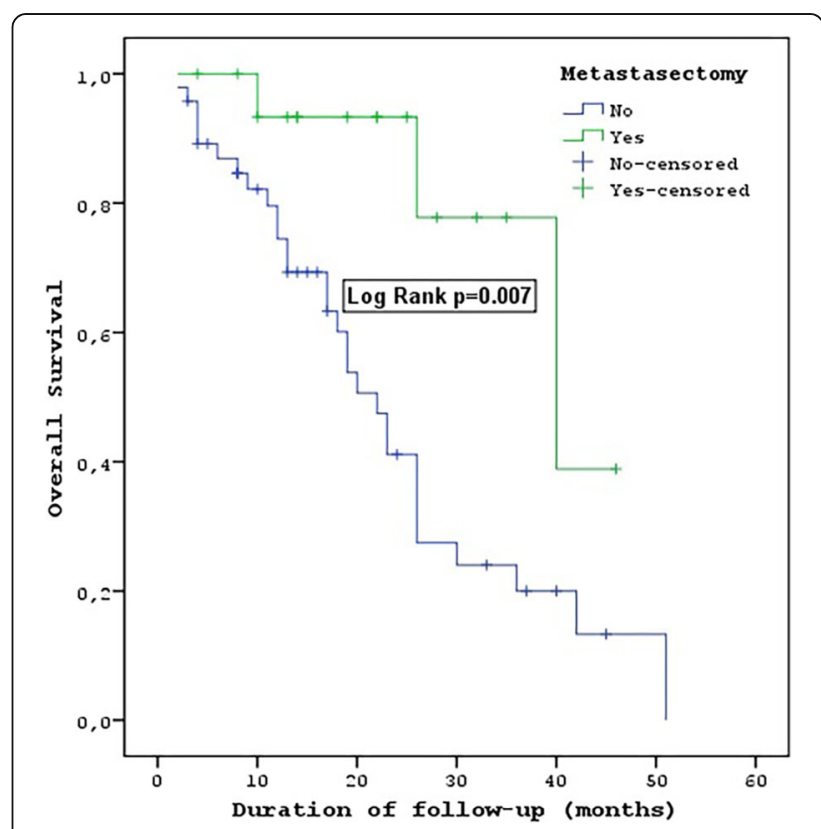

Fig. 4 OS metastasectomy of patients with wild-type KRAS and wildtype NRAS mCRC 


\section{Acknowledgements}

Not applicable.

\section{Funding}

Not applicable.

\section{Availability of data and materials}

The datasets used and/or analysed during the current study are available from the corresponding author on reasonable request.

\section{Authors' contributions}

CG collected, analysed and interpreted the patient data and has written the original and revised manuscript. NG revised and supervised the article. Both authors read and approved the final manuscript.

\section{Ethics approval and consent to participate}

This retrospective study was approved by the Institutional Ethics Board.

\section{Consent for publication}

Not applicable.

\section{Competing interests}

The authors declare that they have no competing interests.

\section{Publisher's Note}

Springer Nature remains neutral with regard to jurisdictional claims in published maps and institutional affiliations.

Received: 5 July 2017 Accepted: 6 March 2018

Published online: 27 March 2018

\section{References}

1. Engstrom PF, Arnoletti JP, Benson AB 3rd, Chen YJ, Choti MA, Cooper HS, Covey A, Dilawari RA, Early DS, Enzinger PC, et al. NCCN clinical practice guidelines in oncology: colon cancer. J Natl Compr Cancer Netw. 2009;7(8): 778-831.

2. Douillard JY, Oliner KS, Siena S, Tabernero J, Burkes R, Barugel M, Humblet $Y$, Bodoky G, Cunningham D, Jassem J, et al. Panitumumab-FOLFOX4 treatment and RAS mutations in colorectal cancer. N Engl J Med. 2013; 369(11):1023-34.

3. Bokemeyer C, Kohne CH, Ciardiello F, Lenz HJ, Heinemann V, Klinkhardt U, Beier F, Duecker K, van Krieken JH, Tejpar S. FOLFOX4 plus cetuximab treatment and RAS mutations in colorectal cancer. Eur J Cancer. 2015;51(10): 12431252.

4. Van Cutsem E, Lenz HJ, Kohne CH, Heinemann V, Tejpar S, Melezinek I, Beier F, Stroh C, Rougier P, van Krieken JH, et al. Fluorouracil, leucovorin, and irinotecan plus cetuximab treatment and RAS mutations in colorectal cancer. J Clin Oncol. 2015:33(7):692-700.

5. Cohn AL, Shumaker GC, Khandelwal P, Smith DA, Neubauer MA, Mehta N, Richards D, Watkins DL, Zhang K, Yassine MR. An open-label, single-arm, phase 2 trial of panitumumab plus FOLFIRI as second-line therapy in patients with metastatic colorectal cancer. Clin Colorectal Cancer. 2011; 10(3):171-7.

6. Mitchell EP, Piperdi B, Lacouture ME, Shearer $H$, lannotti N, Pillai MV, Xu F, Yassine $M$. The efficacy and safety of panitumumab administered concomitantly with FOLFIRI or irinotecan in second-line therapy for metastatic colorectal cancer: the secondary analysis from STEPP (Skin Toxicity Evaluation Protocol With Panitumumab) by KRAS status. Clin Colorectal Cancer. 2011; 10(4):333-9.

7. Venook AP, Niedzwiecki D, Lenz H-J, Innocenti F, Mahoney MR, O'Neil BH, Shaw JE, Polite BN, Hochster HS, Atkins JN et al: CALGB/SWOG 80405: phase III trial of irinotecan/5-FU/leucovorin (FOLFIRI) or oxaliplatin/5-FU/leucovorin (mFOLFOX6) with bevacizumab (BV) or cetuximab (CET) for patients (pts) with KRAS wild-type (wt) untreated metastatic adenocarcinoma of the colon or rectum (MCRC). J Clin Oncol 2014, 32(18_suppl):LBA3-LBA3.

8. Schwartzberg LS, Rivera F, Karthaus M, Fasola G, Canon JL, Hecht JR, Yu H, Oliner KS, Go WY. PEAK: a randomized, multicenter phase II study of panitumumab plus modified fluorouracil, leucovorin, and oxaliplatin (mFOLFOX6) or bevacizumab plus mFOLFOX6 in patients with previously untreated, unresectable, wild-type KRAS exon 2 metastatic colorectal cancer. J Clin Oncol. 2014;32(21):2240-7.
9. Bennett L, Zhao Z, Barber B, Zhou X, Peeters M, Zhang J, Xu F, Wiezorek J, Douillard JY. Health-related quality of life in patients with metastatic colorectal cancer treated with panitumumab in first- or second-line treatment. Br J Cancer. 2011;105(10):1495-502.

10. Peeters M, Price TJ, Cervantes A, Sobrero A, Ducreux MP, André T, Lordick F, Punt CJA, Koukakis R, Terwey J, et al. Tumour shrinkage and response outcomes during second-line panitumumab (pmab) + FOLFIRI vs FOLFIRI treatment. Ann Oncol. 2014;25(suppl_4):iv186-7.

11. Kohne CH, Hofheinz R, Mineur L, Letocha H, Greil R, Thaler J, Fernebro E, Gamelin E, Decosta L, Karthaus M. First-line panitumumab plus irinotecan/5fluorouracil/leucovorin treatment in patients with metastatic colorectal cancer. J Cancer Res Clin Oncol. 2012;138(1):65-72.

12. Freeman DJ, Juan T, Reiner M, Hecht JR, Meropol NJ, Berlin J, Mitchell E, Sarosi I, Radinsky R, Amado RG. Association of K-ras mutational status and clinical outcomes in patients with metastatic colorectal cancer receiving panitumumab alone. Clin Colorectal Cancer. 2008;7(3):184-90.

13. Abad A, Massuti B, Gravalos C, Escudero P, Guillen C, Manzano JL, Gomez MA, Safont MJ, Plazas JG, Sastre J et al: Phase II trial of panitumumab plus FOLFOX4 or FOLFIRI in subjects with KRAS wild-type colorectal cancer and liver-limited disease: the PLANET study. J Clin Oncol 2014, 32(15_suppl): 3560-3560.

14. Shitara K, Yonesaka K, Denda T, Yamazaki K, Moriwaki T, Tsuda M, Takano T, Okuda H, Nishina T, Sakai K, et al. Randomized study of FOLFIRI plus either panitumumab or bevacizumab for wild-type KRAS colorectal cancer-WJOG 6210G. Cancer Sci. 2016;107(12):1843-50.

15. Douillard JY, Siena S, Cassidy J, Tabernero J, Burkes R, Barugel M, Humblet Y, Bodoky G, Cunningham D, Jassem J, et al. Final results from PRIME: randomized phase III study of panitumumab with FOLFOX4 for first-line treatment of metastatic colorectal cancer. Annals of oncology : official journal of the European Society for Medical Oncology / ESMO. 2014;25(7):1346-55.

16. Heinemann V, von Weikersthal LF, Decker T, Kiani A, Vehling-Kaiser U, AlBatran SE, Heintges T, Lerchenmuller C, Kahl C, Seipelt G, et al. FOLFIRI plus cetuximab versus FOLFIRI plus bevacizumab as first-line treatment for patients with metastatic colorectal cancer (FIRE-3): a randomised, openlabel, phase 3 trial. Lancet Oncol. 2014;15(10):1065-75.

17. Ciardiello F, Normanno N, Maiello E, Martinelli E, Troiani T, Pisconti S, Giuliani F, Barone C, Carteni G, Rachiglio AM, et al. Clinical activity of FOLFIRI plus cetuximab according to extended gene mutation status by nextgeneration sequencing: findings from the CAPRI-GOIM trial. Annals of oncology : official journal of the European Society for Medical Oncology/ ESMO. 2014;25(9):1756-61.

18. Karthaus M, Hofheinz RD, Mineur L, Letocha H, Greil R, Thaler J, Fernebro E, Oliner KS, Boedigheimer M, Twomey B, et al. Impact of tumour RAS/BRAF status in a first-line study of panitumumab + FOLFIRI in patients with metastatic colorectal cancer. Br J Cancer. 2016;115(10):1215-22

19. Tejpar S, Stintzing S, Ciardiello F, Tabernero J, Van Cutsem E, Beier F, Esser R, Lenz $\mathrm{HJ}$, Heinemann V. Prognostic and predictive relevance of primary tumor location in patients with RAS wild-type metastatic colorectal cancer: retrospective analyses of the CRYSTAL and FIRE-3 trials. JAMA Oncol. 2017; 3(2):194-201.

20. Holch JW, Ricard I, Stintzing S, Modest DP, Heinemann V. The relevance of primary tumour location in patients with metastatic colorectal cancer: a meta-analysis of firstline clinical trials. Eur J Cancer. 2017;70:87-98.

21. Holch JW, Ricard I, Stintzing S, Fischer von Weikersthal L, Decker T, Kiani A, et al. Relevance of liver-limited disease in metastatic colorectal cancer: subgroup findings of the FIRE-3/AIO KRK0306 trial. Int J Cancer. 2018;142(5): 1047-55. https://doi.org/10.1002/ijc.31114. Epub 2017 Nov 7.

22. Jones RP, Malik HZ, Fenwick SW, Poston GJ. Perioperative chemotherapy for resectable colorectal liver metastases: where now? Eur J Surg Oncol. 2013; 39(8):807-11.

23. Köhne CH, Bokemeyer C, Folprecht G, Sartorius U, Schlichting M, Rougier PR, Van Cutsem E. Chemotherapy plus cetuximab in patients with liver-limited or non-liver-limited KRAS wild-type colorectal metastases: a pooled analysis of the CRYSTAL and OPUS studies. J Clin Oncol. 2012;30(suppl; abstr 3562):2012.

24. Giessen C, Fischer von Weikersthal L, Laubender RP, Stintzing S, Modest DP, Schalhorn A, Schulz C, Heinemann V. Evaluation of prognostic factors in liverlimited metastatic colorectal cancer: a preplanned analysis of the FIRE-1 trial. Br J Cancer. 2013;109(6):1428-36.

25. Kataoka K, Kanazawa A, Iwamoto S, Kato T, Nakajima A, Arimoto A. Does "conversion chemotherapy" really improve survival in metastatic colorectal cancer patients with liver-limited disease? World J Surg. 2014;38(4):936-46. 
26. Köhne CH, Poston G, Folprecht G, Ciardiello F, Ronga P, Beier F, Van Cutsem E. FOLFIRI plus cetuximab in patients with liver-limited or non-liver-limited RAS wild-type metastatic colorectal cancer: a retrospective subgroup analysis of the CRYSTAL study. Eur J Surg Oncol. 2016:42(10):1540-7.

27. Ye LC, Liu TS, Ren L, Wei Y, Zhu DX, Zai SY, Ye QH, Yu Y, Xu B, Qin XY, Xu J. Randomized controlled trial of cetuximab plus chemotherapy for patients with KRAS wild-type unresectable colorectal liver-limited metastases. J Clin Oncol. 2013;31(16):1931-8.

28. Folprecht G, Gruenberger T, Bechstein WO, Raab HR, Lordick F, Hartmann JT, Lang H, Frilling A, Stoehlmacher J, Weitz J, Konopke R, Stroszczynski C, Liersch T, Ockert D, Herrmann T, Goekkurt E, Parisi F, Kohne CH. Tumour response and secondary resectability of colorectal liver metastases following neoadjuvant chemotherapy with cetuximab: the CELIM randomised phase 2 trial. Lancet Oncol. 2010;11(1):38-47.

29. Petrelli F, Barni S. Resectability and outcome with anti-EGFR agents in patients with KRAS wild-type colorectal liver-limited metastases: a metaanalysis. Int J Color Dis. 2012;27(8):997-1004.

30. Thaler J, Karthaus M, Mineur L, Greil R, Letocha H, Hofheinz R, Fernebro E, Gamelin E, Banos A, Kohne CH. Skin toxicity and quality of life in patients with metastatic colorectal cancer during first-line panitumumab plus FOLFIRI treatment in a single-arm phase II study. BMC Cancer. 2012;12:438.

\section{Submit your next manuscript to BioMed Central} and we will help you at every step:

- We accept pre-submission inquiries

- Our selector tool helps you to find the most relevant journal

- We provide round the clock customer support

- Convenient online submission

- Thorough peer review

- Inclusion in PubMed and all major indexing services

- Maximum visibility for your research

Submit your manuscript at www.biomedcentral.com/submit

) Biomed Central 